\title{
ResearchArticle
}

\section{Production of vermifertilizer from sugar industry wastes by using vermicompost epigenic earthworm}

\author{
MUTHUKRISHNAN BOOPATHIAYYANAR AND SWAMINATHAN PRABAKARAN
}

\begin{abstract}
SUMMARY
The efforts have been made to convert the sugar industry waste into a value-added product, by employing an epigenic earthworm species for vermicomposting eg. Eisenia foetida, under laboratory conditions. Sugar industry waste was amended with other organic supplements (Cow dung); and ten types of vermicompost were prepared. Vermicomposting of sugar industry waste resulted in total organic carbon (22.10 \pm 0.171 ) but increment in total nitrogen (20.16 \pm 0.142$)$, total potassium (16.76 \pm 0.111$)$ and total phosphorus (19.39 \pm 0.101$)$ was achieved after 14 weeks of E. foetida activity. The C:N ratio decreased with time in all the earthworm worked vermicompost in the range of (1.09 \pm 0.110$)$. E. foetida exhibited maximum value of mean biomass gain $\left(1091.54 \pm 0.481 \mathrm{mg}\right.$ earthworm $\left.^{-1}\right)$, cocoon numbers $\left(0.80 \pm 0.014\right.$ cocoon worm $^{-1}$ day $^{-}$ $\left.{ }^{1}\right)$ in $\mathrm{VC}_{4}$ treatment. The microbial populations in vermicomposting $\left(\mathrm{VC}_{4}\right)$ were enumerated with the dilution plate method, using several media in the presence of earthworms. The microbial populations increased due to earthworm activity. Overall, $\mathrm{VC}_{4}$ vermicompost appeared as an ideal substrate to manage sugar industry waste effectively and these method can be proposed as a low impute basic technology to convert sugar industry waste into value added vermicomposts.
\end{abstract}

Key Words : Cow dung, Earthworm, Eisenia foetida, Press mud, Waste, Sugar industry

How to cite this article : Boopathiayyanar, Muthukrishnan and Prabakaran, Swaminathan (2017). Production of vermifertilizer from sugar industry wastes by using vermicompost epigenic earthworm. Internat. J. Plant Sci., 12 (2): 139-148, DOI: 10.15740/ HAS/IJPS/12.2/139-148.

Article chronicle : Received : 24.02.2017; Revised : 30.04.2017; Accepted : 18.05.2017

\section{MEMBERS OF THE RESEARCH FORUM}

Author to be contacted :

SWAMINATHAN PRABAKARAN, Department of Botany, Annamalai

University, Annamalai Nagar, CHIDAMBRAM (T.N.) INDIA

Email : drprabakarans@gmail.com

Address of the Co-authors:

MUTHUKRISHNAN BOOPATHIAYYANAR, Department of Botany, Annamalai University, Annamalai Nagar, CHIDAMBRAM (T.N.) INDIA

Email : boopathiayyanar@gmail.com 